\title{
Isolation and Purification of Glucans from an Italian Cultivar of Ziziphus jujuba Mill. and In Vitro Effect on Skin Repair
}

\author{
Alessia Fazio ${ }^{1, *,+}$, Chiara La Torre ${ }^{1,+}$, Maria Cristina Caroleo ${ }^{1}$, Paolino Caputo ${ }^{2}$ (D), \\ Pierluigi Plastina ${ }^{1}(\mathbb{D})$ and Erika Cione ${ }^{1}$ \\ 1 Department of Pharmacy, Health and Nutritional Sciences, Department of Excellence 2018-2022, \\ University of Calabria, Edificio Polifunzionale, 87036 Rende (CS), Italy; latorre.chiara@libero.it (C.L.T.); \\ mariacristinacaroleo@virgilio.it (M.C.C.); pierluigi.plastina@unical.it (P.P.); erika.cione@unical.it (E.C.) \\ 2 Department of Chemistry and Chemical Technologies, University of Calabria, 87036 Rende (CS), \\ Italy; paolino.caputo@unical.it \\ * Correspondence: a.fazio@unical.it; Tel.: +39-0984-493013 \\ + Equally contributed.
}

Received: 23 January 2020; Accepted: 18 February 2020; Published: 21 February 2020

\begin{abstract}
Glucans possess a broad spectrum of biological activities. In this context, the present study was performed to isolate glucans from an Italian cultivar of Ziziphus jujuba Mill. at three different harvesting periods, in order to evaluate their effects on wound healing. The dry fruits were subjected to an alkaline extraction and then isolated glucans were purified by dialyzation. The crude and soluble samples were characterized by FT-IR and SEM analyses. Afterwards, total, $\alpha$ - and $\beta$-glucan content was measured using an enzymatic procedure. The results highlighted that the glucan amount increased as the maturation proceeded as well as the $\beta$-glucan percentage, which ranged from 48.2 at the first harvesting to 65.4 at the third harvesting. Furthermore, the effects of isolated glucans on the viability and migration of keratinocytes were evaluated using the in vitro MTT and scratch wound assays. The best proliferative effects on keratinocyte migration have been achieved with soluble glucans from third harvesting at $100 \mu \mathrm{M}$ after 24 and $48 \mathrm{~h}\left({ }^{* * *} p<0.001\right)$. The same treated group showed significant narrowing of the scratch area after $24 \mathrm{~h}$ and complete closure of the injury after $48 \mathrm{~h}$. The findings highlighted the effectiveness of soluble glucans on regeneration of damaged skin.
\end{abstract}

Keywords: Ziziphus jujuba Mill.; glucans; scanning electron microscopy; keratinocytes; MTT assay; scratch assay; wound healing

\section{Introduction}

Ziziphus jujuba Mill. is one of the oldest medicinal plants with a long history of nutrition use as well as diseases treatment [1]. It grows typically in Asia, but also in Australia, the US, and Europe [2,3]. The health benefit of jujube fruits includes its anti-inflammatory [4], and antioxidant activities showing possible pharmacological application [5-7]. Jujube fruits is also applied to the promising area of dermocosmetics, which includes wound healing care [8]. This latter capability is due to several bioactive compounds present in the fruit [8,9]. In recent years, glucans of oats and barley, in particular those ones with a $\beta$ conformation, have just been studied in wound healing, showing multifunctional activities $[8,10,11]$. Glucans are present in various plant-origin foods and therefore can potentially be extracted from a variety of food matrices [12]. Glucans are biologically active biopolymers that exist in different structural organizations, depending on the food matrices [13]. The biological effect of glucans is still stimulating large research efforts of the relationship of their structural characteristics and their ability to interact with biological receptors [14]. In particular, they activate the immune system and 
stimulate defensive response against wounding [8]. This effect is mediated by receptors also located on skin cells such as keratinocytes and fibroblasts [15]. The presence of wound stimulates the organism to develop healing mechanisms to regenerate impaired skin. The cellular events that occur imply any of three complex biological processes: Inflammation, proliferation, and remodeling [16]. After a wound, hemostasis and generation of inflammatory stimuli take place and then activated macrophages produce growth factors and cytokines, which stimulate anti-inflammatory and antibacterial effects, and the migration of dermal fibroblasts to the wound. In turn, differentiated dermal fibroblasts synthesize extracellular matrix, such as a collagen and elastin, and promote dermal contraction in order to accelerate wound closure [17]. $\beta$-Glucans have significant effects on human dermal fibroblast (HDF) proliferation, keratinocyte migration, and procollagen secretion [18]. On the other hand, glucans stimulate the production of growth factors essential for skin, promotes collagen biosynthesis, and ensure moisture and elasticity of skin [19]. For this reason, the present study was designed to perform isolation, purification, and characterization of glucans extracted from jujube fruits (Ziziphus jujuba Mill.) at three different harvesting period, and to evaluate their effect on skin repair using a human keratinocyte cell line.

The further aim was also to verify if different percentages of alpha and beta forms, contained in the glucans extracted from jujubes, can influence the regeneration of damaged skin.

\section{Materials and Methods}

\subsection{Chemicals and Reagents}

Solvents of analytical grade for this study: Acetone, methanol, ethanol, demineralized water, hydrochloric acid, and dimethyl sulfoxide (DMSO) were purchased from Carlo Erba Reagent (Milan, Italy). Sodium carbonate, dialysis tube (Molecular Weight Cut Off 12400), and 3-(4,5-dimethylthiasol-2-yl)-2,4-diphenyltetrazolium bromide (MTT) were purchased from Sigma-Aldrich (Milan, Italy). The glucans content was determined by mushroom and yeast $\beta$-glucan kit (Cat. No. K-YBGL Megazyme International, Bray, County Wicklow, Ireland), based on the method published by McCleary and Codd [20]. Human immortalized HaCat keratinocyte cell line was obtained from CLS Cell Lines Service GmbH (Eppelheim, Germany) after a Material Transfer Agreement, and Dulbecco's modified Eagle's medium (DMEM) and fetal bovine serum (FBS) were obtained from Thermo Fisher Scientific (Waltham, MA, USA).

\subsection{Plant Material}

Ziziphus jujube fruits were harvested in the locality of Rombiolo (Latitude: $38^{\circ} 35^{\prime} 34^{\prime \prime} 08 \mathrm{~N}$; Longitude: $16^{\circ} 0^{\prime} 9^{\prime \prime} 00 \mathrm{E}$, Calabria, Southern Italy), in the period from September to October 2017. The fruits were picked up from the same area three times, at a distance of 15 days from each other. The round-shaped drupes at first harvesting (J1) had green color; at second harvesting (J2) were yellow green with mahogany-colored spots; at the third harvesting (J3), the color was almost completely red. Twenty fruits were picked at random from a single tree in order to calculate the size: Fruit length and diameter were measured by using a vernier caliper (Table 1). The fruits were then washed and then preserved under nitrogen, frozen at $-20{ }^{\circ} \mathrm{C}$ before undergoing the freeze drying process (Telstar freeze-dryer, mod. Cryodos, Terrassa, Barcelona, Spain). Furthermore, lyophilized fruits were pitted, manually ground in a mortar with a pestle, sieved through a 60 -mesh screen, and stored at $-20^{\circ} \mathrm{C}$ as a flour. 
Table 1. Length and diameter of jujube fruits (Ziziphus jujuba Mill.) during ripening.

\begin{tabular}{cccc}
\hline Harvesting & J1 & J2 & J3 \\
\hline Length $*(\mathrm{~mm})$ & $19 \pm 1$ & $19.7 \pm 0.4$ & $21.2 \pm 0.7$ \\
Diameter $^{*}(\mathrm{~mm})$ & $4.7 \pm 0.5$ & $6.5 \pm 0.2$ & $7.8 \pm 0.2$ \\
\hline & * average of $n$ measurement \pm SD. $n=20$.
\end{tabular}

\subsection{Extraction of Glucans}

The procedure used consisted of 3 phases: (a) Aqueous alkaline extraction of glucans and solubilized proteins, (b) acidic precipitation of proteins at their isoelectric point, and (c) precipitation of glucans by absolute ethanol [21]. The protocol for the sequential extraction of glucans from dried jujubes at laboratory scale is summarized in Figure 1. Briefly, J1, J2, and J3 flours (1 g) were subjected to purification phase in order to remove lipids, vitamin, polyphenols, monosaccharides, and disaccharides [22]. The phase consisted of extraction by using solvents at different polarity in sequence (acetone first, followed by methanol, and finally ethanol at $70 \%$ in bi-distillate water). The purification was carried out at room temperature (RT) for $2 \mathrm{~h}$ with each solvent $(3 \times 10 \mathrm{~mL})$. The resulting solid residue was added with a solution of sodium carbonate $(20 \% w / v)$ and then the mixture was stirred vigorously for $30 \mathrm{~min}$ in a water bath at $55^{\circ} \mathrm{C}$. The suspension was centrifuged for $30 \mathrm{~min}$ at 15,000 rpm (Model J2-21, Beckman Instrument Co., Mississauga, ON, Canada) and the supernatant pH was adjusted to 4.5 (isoelectric point of proteins) with $2 \mathrm{M}$ of $\mathrm{HCl}$. The mixture was re-centrifuged for $30 \mathrm{~min}$ at $15,000 \mathrm{rpm}$ in order to separate the precipitated protein, which were thrown away [23]. The clarified supernatant, containing glucans fraction, was treated with an equal volume of ethanol $100 \%$ and left at $4{ }^{\circ} \mathrm{C}$ overnight. After that, the solution was centrifuged for $30 \mathrm{~min}$ at $15,000 \mathrm{rpm}$ to separate the precipitate, containing crude glucans, which was washed twice with ethanol $100 \%$ and vacuum dried. The crude glucans were dialyzed, overnight at RT, by using a $12400 \mathrm{MCWO}$ dialysis tubing, in order to remove low-molecular-weight molecules [24]. The solution from inside the dialysis tube was centrifuged for $30 \mathrm{~min}$ at 15,000 rpm and then the supernatant was freeze dried to calculate the yield of the water-soluble fraction. Both isolated fractions, crude and water-soluble glucans, were then characterized by FT-IR and SEM analysis. The extractions followed by purification were performed on three samples of jujube powder from each stage of harvesting.
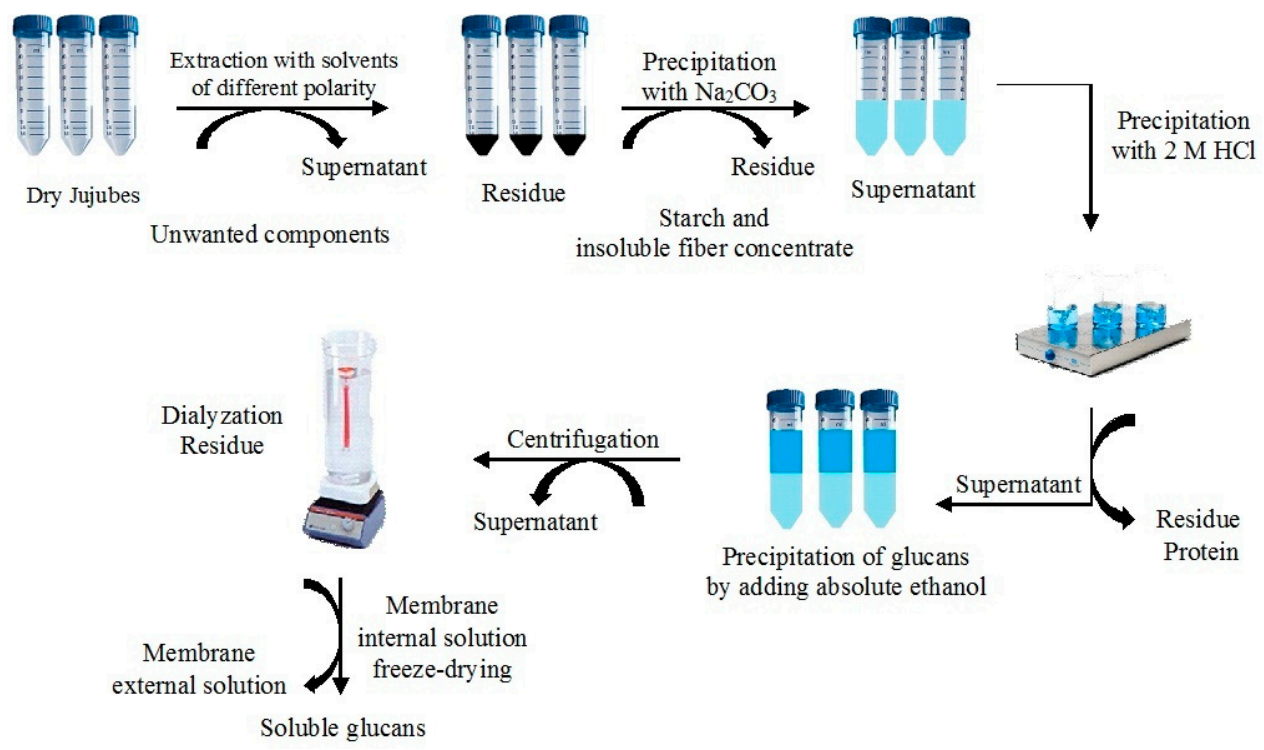

Figure 1. Scheme of the extraction of crude and soluble glucans. 


\subsection{Glucan Recovery Test}

Recovery rate calculation was carried out in order to determine the validity and applicability of the experimental procedure. For this purpose, an experimental plan that involved the analysis of fortified samples, was realized. The fortified sample were prepared by spiking jujube flour at each stage of maturation (J1, J2, and J3) ( $1 \mathrm{~g})$ at the beginning of the extraction procedure with different amount of glucan standard. Five spiking levels were performed: 30, 60, 90, 120 and $150 \mathrm{mg} \mathrm{g}^{-1}$. Four replicates for each spiking level were performed.

\subsection{Detection of Glucan Content}

The total glucan content was determined in triplicate using the $\beta$-glucan assay kit from Megazyme (Cat. No. K-YBGL, Astori Tecnica Snc, Poncarale (BS), Italy) [22]. The scheme of procedural sequences is shown in Figure 2A. Briefly, J1, J2, and J3 flours $(0.1 \mathrm{~g})$ were added with $12 \mathrm{M}$ ice-cold sulphuric acid $(2 \mathrm{~mL})$. The mixture was stirred vigorously and incubated in an ice-cold water bath for $2 \mathrm{~h}$. Then, distilled water $(12 \mathrm{~mL})$ was added to each sample and the suspension was kept at the boiling temperature in a water bath $\left(\mathrm{T}=100{ }^{\circ} \mathrm{C}\right)$ for $2 \mathrm{~h}$, shaking it occasionally in a vortex mixer during this time. After cooling to room temperature, each sample was added with $10 \mathrm{M} \mathrm{KOH}(6 \mathrm{~mL})$ and $200 \mathrm{mM}$ sodium acetate buffer ( $\mathrm{pH}$ 5.0) up to the volume of $100 \mathrm{~mL}$. After centrifugation at $1500 \mathrm{rpm}$ for $10 \mathrm{~min}$, an aliquot of the supernatant $(0.1 \mathrm{~mL})$ was mixed with exo-1,3- $\beta$-glucanase $(20 \mathrm{U} / \mathrm{mL})$ plus $\beta$-glucosidase $(4 \mathrm{U} / \mathrm{mL})(0.050 \mathrm{ml})$ and incubated at $40{ }^{\circ} \mathrm{C}$ for $60 \mathrm{~min}$. Then, the mixture was incubated at $40{ }^{\circ} \mathrm{C}$ for $20 \mathrm{~min}$ with glucose-oxidase/peroxidase-reagent (GOPOD, $3 \mathrm{~mL}$ ). Total glucans were evaluated by the spectrophotometer analysis at $\lambda=510 \mathrm{~nm}$ (Model UV-vis, JASCO, V-550) against the blank ( $0.2 \mathrm{~mL}$ of $200 \mathrm{mM}$ sodium acetate buffer at $\mathrm{pH}$ 5.0, plus $3 \mathrm{~mL}$ of GOPOD) and against the D-glucose standard solution $(1 \mathrm{mg} / \mathrm{mL})$, incubated with GOPOD reagent (Figure $2 \mathrm{~A})$. The $\alpha$-glucan content was determined after incubation $\left(\mathrm{T}=40^{\circ} \mathrm{C} ; \mathrm{t}=30 \mathrm{~min}\right)$ of the suspension of jujube flour $(0.1 \mathrm{~g})$ in $2 \mathrm{M} \mathrm{KOH}(2 \mathrm{~mL})$ added by $1.2 \mathrm{M}$ sodium acetate buffer $(\mathrm{pH} 3.8,8 \mathrm{~mL})$ with $0.2 \mathrm{~mL}$ of a mixture of amyloglucosidase plus invertase. Each sample was centrifuged at $1500 \mathrm{rpm}$ for $10 \mathrm{~min}$ and $0.1 \mathrm{~mL}$ of the supernatant were mixed with $0.1 \mathrm{~mL}$ of $200 \mathrm{mM}$ of sodium acetate buffer ( $\mathrm{pH}$ 5.0) and $3 \mathrm{~mL}$ of GOPOD (Figure 2B). $\beta$-Glucan content was determined by difference between total and $\alpha$-glucan contents.

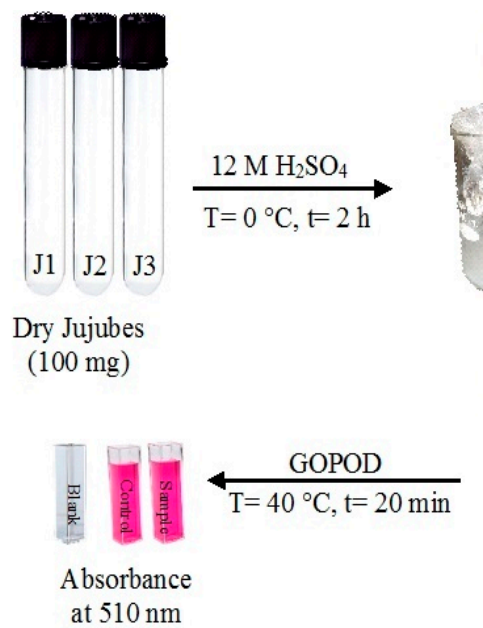

at $510 \mathrm{~nm}$
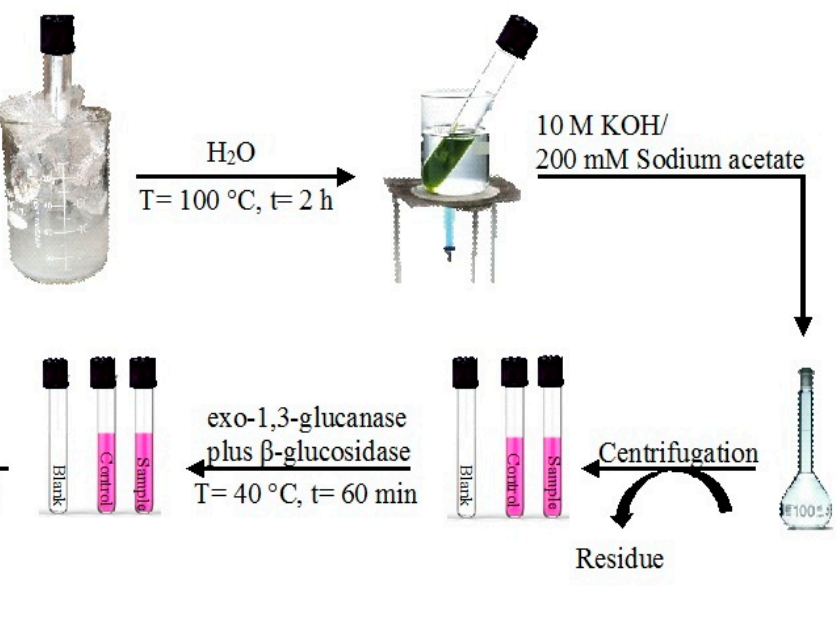

(A)

Figure 2. Cont. 


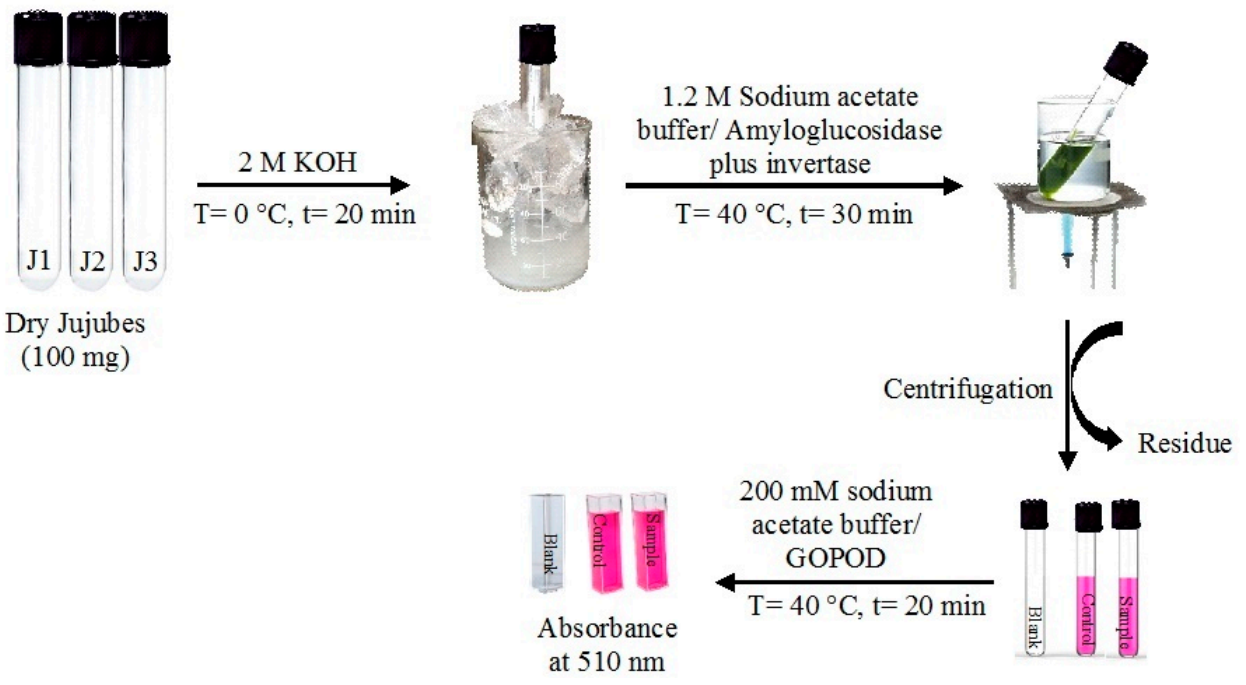

(B)

Figure 2. (A) Total glucan content and (B) $\alpha$-glucan content.

\subsection{FT-IR Spectroscopic Analysis}

Both crude and soluble glucans1 were characterized, according to their fingerprint, by FT-IR spectroscopy using a Bruker ALPHA FT-IR spectrometer (Billerica, MA, USA) equipped with a A241/D reflexion module. The sample and $\mathrm{KBr}$ were pulverized in an agate mortar and the powder was compressed with a press at a force of 6 tons [25]. Film spectra were recorded at $4000-400 \mathrm{~cm}^{-1}$ wavelength range and $4 \mathrm{~cm}^{-1}$ resolutions.

\subsection{Scanning Electron Microscopy}

The characterization of sample surface morphology was acquired by a Scanning Electron Microscope (SEM) (Field Emission SEM FEI Quanta 200, Thermo Fisher Scientific, Hillsboro, OR, USA) and Electron Probe Micro Analyzer (EPMA, JEOL JXA 8230t, Kyoto, Japan), equipped with wavelength dispersive (WDS) in order to determine both the elemental composition and spatial distribution. The surface of the samples was coated by a $5 \mathrm{~nm}$ thick layer of Carbon, using a Carbon Coater QUORUM Q150T-ES (Darmstadt, Germany). The operating conditions for SEM analysis were the following: HV $15 \mathrm{KeV}$; Probe Current 10-20 nA; working Distance of $11 \mathrm{~mm}$; image BSE signal; detector image: Solid state detector (SSD); Everhart Thornley SE detector (ETD, Thermo Fisher Scientific, Hillsboro, OR, USA); image size: $2560 \times 1920$ pixel. Morphological pictures were acquired by scattered electron signal (SE signal) while crystal observation was performed by backscattered electrons technique (BSE signal). The WDS analytical conditions (Spectrometers WDS XCE type and X type) were: An accelerating voltage of $15 \mathrm{keV}$ and a Faraday cup current of $10 \mathrm{nA}, 11 \mathrm{~mm}$ as working distance. All WDS analysis were carried out at room temperature $\left(22 \pm 1^{\circ} \mathrm{C}\right)$ and for each sample, three points were analyzed to determine the average value for $\mathrm{N}, \mathrm{C}$, and $\mathrm{O}$ content, which should be the major elements for isolated glucans.

\subsection{Cell Culture}

Human immortalized keratinocyte cell line HaCat was cultured into 24-well plate (Falcon, Becton-Dickinson, Lincoln Park, NJ, USA) at a concentration of $1 \times 10^{5}$ cells $37^{\circ} \mathrm{C}, 5 \% \mathrm{CO}_{2}$, in Dulbecco's modified Eagle's (DMEM) supplemented with $10 \%$ fetal bovine serum (FBS) and $1 \%$ antibiotics (10.000 $\mu \mathrm{g} \mathrm{mL}^{-1}$ streptomycin and 10.000 unit $\mathrm{mL}^{-1}$ penicillin), and incubated overnight at $37^{\circ} \mathrm{C}$ in a humidified $5 \% \mathrm{CO}_{2}$ atmosphere. Cell counting was achieved using Countess Automated Cell 
Counter (Thermo Fisher Scientific, Waltham, MA, USA) by Trypan Blue staining. Glucan samples, prepared using water as solvent, were solubilized in complete medium $(0.5 \mathrm{~mL})$.

\subsection{Cell Viability MTT Assay}

Cell viability was estimated by MTT, which is reduced to an insoluble, colored, formazan product by mitochondrial succinate dehydrogenase [26-28]. The amount of color produced is directly proportional to the number of viable cells. A day before the assay, HaCaT cells were seeded in 24-well plates at an optimum per $100 \mu \mathrm{l}$ medium per well. The cell suspensions were then incubated at $37^{\circ} \mathrm{C}$ to enable cell attachment. After $24 \mathrm{~h}$, the cells were treated with $100 \mu \mathrm{l}$ of each concentration of diluted glucan samples. The concentrations considered for crude and soluble glucans from J1, J2, and J3, were $50 \mu \mathrm{g} \mathrm{mL}^{-1}$ and $100 \mu \mathrm{g} \mathrm{mL}{ }^{-1}$. All concentrations were in triplicates. HaCat cells were incubated with prepared samples in 24-well-plates for $24 \mathrm{~h}$. After incubation, the medium was discarded and refreshed with additional $0.5 \mathrm{~mL}$ of medium and $50 \mu \mathrm{L}$ of MTT $\left(5 \mathrm{mg} \mathrm{mL}^{-1}\right)$ was added to the wells and incubated for $6 \mathrm{~h}$ at $37^{\circ} \mathrm{C}$. After that, the medium was discarded, the cells washed twice using PBS, and $200 \mu \mathrm{L}$ of DMSO was added to dissolve the colored formazan crystals agitating the plates on a shaker for $5 \mathrm{~min}$, under basic condition [27]. The optical density (OD) was read at $545 \mathrm{~nm}$ using a microtiter plate reader (Synergy H1 by BioTeck, Winooski, VT, USA). The results obtained were normalized to percent of control (wells without glucans) and plotted against glucan sample concentration. Cell viability was calculated following the Equation (1):

$$
\text { Viability }(\%)=(\text { Sample OD/Control OD }) \times 100
$$

\subsection{In Vitro Scratch Test}

$\mathrm{HaCaT}$ cells were plated into three 6-well plate (one for each soluble glucan) in the presence of DMEM, $10 \% \mathrm{FBS}$, and incubated at $37^{\circ} \mathrm{C}$ in a humidified $5 \% \mathrm{CO}_{2}$ atmosphere. After attachment of the cells to the plate, DMEM was removed and the adherent cell layer was scraped in a straight line using a sterile $2 \mu \mathrm{L}$ pipette tip in order to create a scratch. Cellular debris were removed by extensive washing with PBS. Then, the cells were treated with DMEM and 10\% FBS containing glucan samples at different concentrations $\left(10,20,50\right.$, and $100 \mu \mathrm{g} \mathrm{mL} \mathrm{L}^{-1}$ ). The cells were then incubated at $37^{\circ} \mathrm{C}$ in a humidified $5 \% \mathrm{CO}_{2}$ atmosphere for 24 and $48 \mathrm{~h}$. The scratch area was periodically imaged, at 0,24 , and $48 \mathrm{~h}$ acquired at $40 \times$ of magnification (Leica DMIL, Buccinasco (MI), Italy) in clear field. The experiments were performed in triplicate.

\subsection{Statistical Analysis}

Unless otherwise indicated, statistical significance was determined by a two-tailed ANOVA with Bonferroni comparison correction. $p$-value of $<0.05$ was regarded as significant. Results are expressed as mean $\pm \mathrm{SD}$.

\section{Results and Discussion}

\subsection{Extraction of Glucans}

After removal of lipids and soluble compounds with acetone, methanol, and aqueous ethanol, in order to facilitate the complete separation of glucans, the extraction process involved alkaline extraction to remove starch, acidic precipitation of free proteins, and precipitation from absolute ethanol. The raw fractions produced underwent the dialysis process, resulting in soluble fractions, which dissolved in water rapidly and easily. The yields ( $w / w)$ of crude and soluble glucans are reported in Table 2 . Data reported in the table highlighted that the glucan content increased as the maturation proceeded. The recovery of crude samples was $13.8 \pm 2.9 \mathrm{mg} \mathrm{g}^{-1}$ at the first harvesting period, $28.2 \pm 1.2 \mathrm{mg} \mathrm{g}^{-1}$ at the second harvesting period, and $38.2 \pm 0.8 \mathrm{mg} \mathrm{g}^{-1}$ at the third. The J1 soluble fraction was found to 
be one-third of the crude sample $\left(4.7 \pm 0.6 \mathrm{mg} \mathrm{g}^{-1}\right)$, but $\mathrm{J} 2$ and J3 soluble fractions were reduced by only 1.6-fold compared with raw samples (17.8 $\pm 0.8 \mathrm{mg} \mathrm{g}^{-1}$ and $24.4 \pm 0.4 \mathrm{mg} \mathrm{g}^{-1}$, respectively).

Table 2. Recovery of crude and soluble glucans from jujube fruits at three harvesting periods.

\begin{tabular}{cccc}
\hline Harvesting period & Glucans & $\begin{array}{c}\text { Recovery } \\
\left(\mathbf{m g ~}^{\mathbf{1}} \mathbf{)}\right.\end{array}$ & $\begin{array}{c}\text { Yield } \\
\mathbf{( \% )}\end{array}$ \\
\hline \multirow{2}{*}{$\mathbf{J 1}$} & Crude & $13.8 \pm 2.9$ & 1.4 \\
& Soluble & $4.7 \pm 0.6$ & 0.5 \\
\hline \multirow{2}{*}{ J2 } & Crude & $28.2 \pm 1.2$ & 2.8 \\
& Soluble & $17.8 \pm 0.8$ & 1.8 \\
\hline \multirow{2}{*}{ J3 } & Crude & $38.2 \pm 0.8$ & 3.8 \\
& Soluble & $24.4 \pm 0.4$ & 2.4 \\
\hline
\end{tabular}

a Average values of three extractions \pm SD.

The recovery rate is defined as the ratio between the amount of glucan standard and glucan recovered by extraction from the spiked sample. The average recovery rate was calculated for each stage of harvesting at all validation levels: The value for glucans from J1 was $90 \pm 5 \%$, for J2 was $88 \pm 4 \%$, and for J3 was $91 \pm 6 \%$. The detailed results are reported in Table 3 . The data obtained proved the applicability and reproducibility of the extraction procedure used.

Table 3. Validation results for recovery results ${ }^{\mathrm{a}}$.

\begin{tabular}{|c|c|c|c|c|c|c|c|c|c|c|c|c|}
\hline & \multicolumn{12}{|c|}{ Level (mg g-1) } \\
\hline & \multicolumn{2}{|c|}{30} & \multicolumn{2}{|c|}{60} & \multicolumn{2}{|c|}{90} & \multicolumn{2}{|c|}{120} & \multicolumn{2}{|c|}{150} & \multicolumn{2}{|c|}{ Average } \\
\hline & $\mathbf{R}$ & $\mathrm{CV}$ & $\mathbf{R}$ & $\mathrm{CV}$ & $\mathbf{R}$ & $\mathrm{CV}$ & $\mathbf{R}$ & $\mathrm{CV}$ & $\mathbf{R}$ & $\mathrm{CV}$ & $\mathbf{R}_{\text {tot }}$ & $\mathrm{CV}$ \\
\hline J1 & 87 & 5 & 88 & 3 & 92 & 8 & 90 & 3 & 93 & 6 & 90 & 5 \\
\hline $\mathrm{J} 2$ & 89 & 3 & 86 & 5 & 85 & 3 & 88 & 4 & 92 & 5 & 88 & 4 \\
\hline $\mathrm{J} 3$ & 92 & 5 & 88 & 7 & 89 & 4 & 95 & 8 & 91 & 6 & 91 & 6 \\
\hline
\end{tabular}

${ }^{\mathrm{a}} \mathrm{R}=$ average of 5 experiments (\%); $\mathrm{CV}=$ coefficient of variation (\%). J1 (jujube from first harvesting); J2 (jujube from the second harvesting); J3 (jujube from the third harvesting).

\subsection{FT-IR Spectroscopic Analysis}

Infrared spectra of crude and soluble glucans showed the characteristic bands of the major functional groups in the $4000-400 \mathrm{~cm}^{-1}$ IR region (Figure 3). The IR band centered around $3422-3445 \mathrm{~cm}^{-1}$ indicated the symmetrical and asymmetric stretching of the $\mathrm{OH}$ groups, contained in a significant number in the glucan backbone. The bands at $2922-2924 \mathrm{~cm}^{-1}$ and $2859 \mathrm{~cm}^{-1}$ corresponded to $\mathrm{CH}_{2}$ stretching vibrations of $\mathrm{CH}_{2} \mathrm{OH}$ groups. The $1500-1800 \mathrm{~cm}^{-1}$ region of IR spectra showed two bands at $1609-1640 \mathrm{~cm}^{-1}$ (the amide I) and $1509-1527 \mathrm{~cm}^{-1}$ (the amide II), which indicated the presence of the amide bond and therefore of proteins in the sample generating the stretching of the $\mathrm{CN}$ and NH groups $[29,30]$. The IR peaks in the region of $1200-1440 \mathrm{~cm}^{-1}$ were originated by in-plane ring deformation including $\mathrm{CH}$ and $\mathrm{OH}$ bending modes. The band around $1034 \mathrm{~cm}^{-1}$ in the region of 990-1200 $\mathrm{cm}^{-1}$ indicated the COC and CC stretching vibrations of the glucosides ring, which are characteristic for polysaccharides and can be used for their identification [31]. The $950-750 \mathrm{~cm}^{-1}$ region, called "anomeric region", is sensitive to anomeric structure around glycosidic bond of the glucopiranose rings: The $\alpha$-linkage is indicated by a band around $850-780 \mathrm{~cm}^{-1}$ and at $920-870 \mathrm{~cm}^{-1}$ for $\beta$-linkage. The presence of absorption bands at $895-876 \mathrm{~cm}^{-1}$ and at $783-800 \mathrm{~cm}^{-1}$ confirmed, respectively, $\beta$ - and $\alpha$-configurations of the isolated glucans [32,33]. FT-IR spectra of raw and soluble glucans at all stages of harvesting showed no significant differences regarding the bands characterizing the structure of glucans. Only variations in the absorption intensity of the bands could be observed 
depending on the maturation stages. Spectroscopic analysis shows that the different collection stages did not involve structural changes.
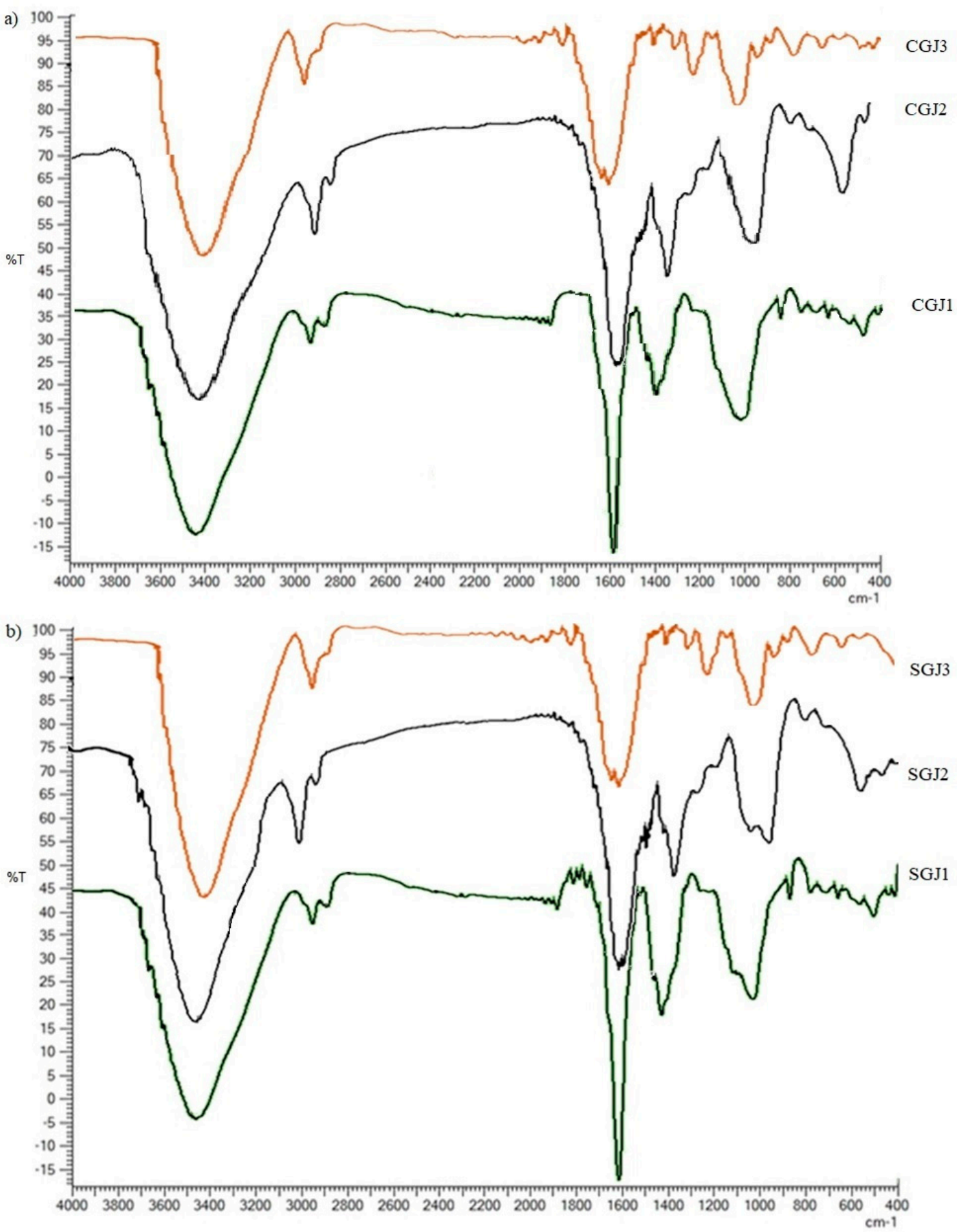

Figure 3. The Fourier transform infrared spectra (FT-IR) of crude (a) and soluble (b) glucans. CGJ1 (crude glucans from jujubes of first harvesting); CGJ2 (crude glucans from jujubes of second harvesting); CGJ3 (crude glucans of jujubes at third harvesting); SGJ1 (soluble glucans from jujubes of first harvesting); SGJ2 (soluble glucans from jujubes of second harvesting); SGJ3 (soluble glucans from jujubes of third harvesting). 


\subsection{Detection of Glucan Content}

A specific enzymatic procedure using yeast glucan assay kit (Megazyme, Astori Tecnica Snc, Poncarale (BS), Italy) was performed in order to determine total glucans and $\alpha$ - and $\beta$-glucans. In this approach, controlled acid hydrolysis followed by incubation with specific enzyme ensured complete hydrolysis of glucans to glucose, which was specifically measured with GOPOD reagent. This acid-enzymatic method minimizes the loss of glucose through secondary reactions. It confirmed the results obtained with the alkaline extraction, namely that the total content of the glucans increased as the fruit ripening proceeds (Table 4). The highest glucan content, recovered from J3, was $26.6 \mathrm{mg}$ $\mathrm{g}^{-1}$, while the lowest amount was obtained from J1 $\left(19.5 \mathrm{mg} \mathrm{g}^{-1}\right)$. Also, the content of $\alpha$-glucans remained almost constant from the first to the third harvesting stages but compared to total glucans, decreased by about $15 \%$. $\beta$-glucan content at the third stage was almost twice as much in relation to the first stage, ranging from $9.4 \mathrm{mg} \mathrm{g}^{-1}$ to $17.4 \mathrm{mg} \mathrm{g}^{-1}$. $\beta$-glucan percentage content with respect to total glucans increased from 48.2 to $65.4 \%$ (Figure 4 ).

Table 4. $\alpha$ - and $\beta$-Glucan content from jujubes.

\begin{tabular}{|c|c|c|c|}
\hline Samples & $\begin{array}{l}\text { Total Glucans } \\
\quad\left(\mathrm{mg} \mathrm{g}^{-1}\right)\end{array}$ & $\begin{array}{c}\alpha \text {-Glucans } \\
\left(\mathrm{mg} \mathrm{g}^{-1}\right)\end{array}$ & $\begin{array}{c}\beta \text {-Glucans }{ }^{a} \\
\left(\mathrm{mg} \mathrm{g}^{-1}\right)\end{array}$ \\
\hline $\mathrm{J} 1$ & $19.5 \pm 2.0$ & $10.1 \pm 0.5$ & $9.4 \pm 0.8$ \\
\hline $\mathrm{J} 2$ & $21.2 \pm 1.3$ & $9.0 \pm 0.9$ & $12.2 \pm 0.9$ \\
\hline $\mathrm{J} 3$ & $26.6 \pm 1.6$ & $9.2 \pm 0.5$ & $17.4 \pm 1.1$ \\
\hline
\end{tabular}

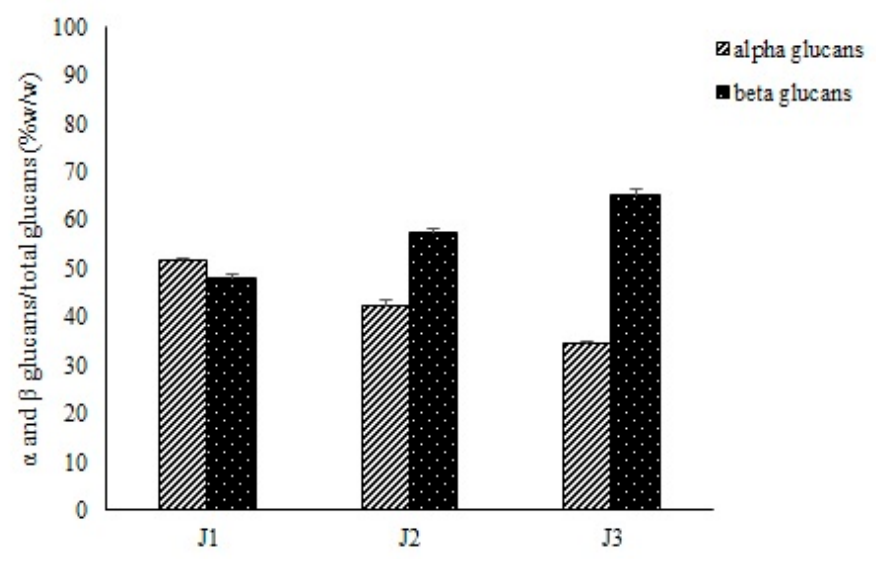

Figure 4. Percentage content of $\alpha$ - and $\beta$-glucans compared to total glucans.

\subsection{Scanning Electron Microscopy}

Scanning electron microscopy was performed observing the surface structural differences of the jujube glucans at each stage of harvesting, before and after dialysis. The study conditions were the same for all sample: Three magnifications equal to $100 \times, 2500 \times$, and $5000 \times$ for a scale equal to $1 \mathrm{~mm}$ for the first magnification only and $20 \mu \mathrm{m}$ for the other (Figure 5). The surface of crude glucans (CG) from J1 (CGJ1) showed a granular appearance with an irregular and smaller particle size distribution. In fact, at high magnifications $(2500 \times-5000 \times)$, the presence of crystals with the size of the order of microns was evident. The CGJ2 had an amorphous matrix, while maintaining a certain degree of crystallinity. The presence of conchoidal fractures, typically of an amorphous material, characterized the extracted sample from CGJ3 (Figure 5). The higher magnifications showed areas with microcrystalline structure. The structural differences between the three glucans, ranging from "pseudo-crystalline" in CGJ1, to the predominantly amorphous of CGJ3, through an intermediate structure, both amorphous and crystalline, of CGJ2, were probably a consequence of the different 
stage of harvesting that affect the microstructures of glucans. Soluble glucans (SG) from J1, J2, and J3 (SGJ1, SGJ2, and SGJ3, respectively) were quite similar at low magnifications (100X). The differences could be observed just at higher magnifications $(2500 \times-5000 \times)$. The surface of SGJ1 showed a sheeting structures, while the one of SGJ2 evidenced changes in the morphology characterized by a film structure on which some filaments were visible. The filamentous structures appeared dominant on the surface of samples of SGJ3. Anyhow, the morphological differences between crude and soluble samples were evident (Figure 5).

CG

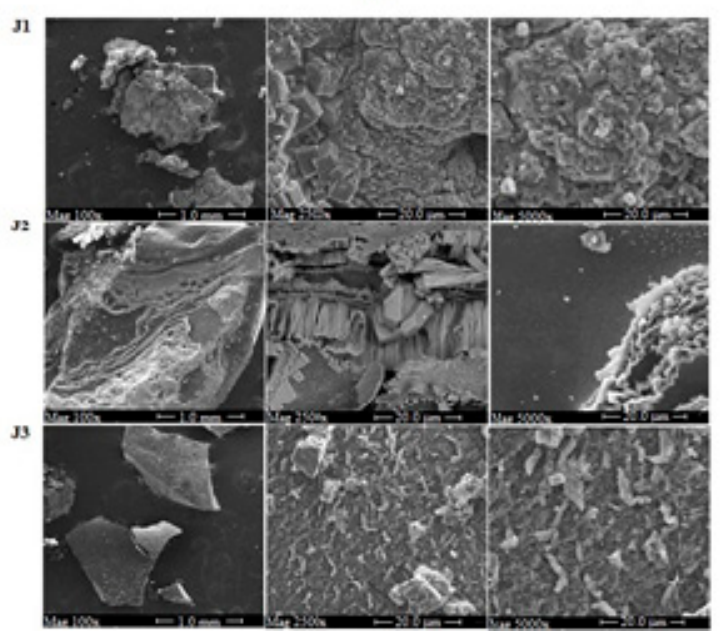

SG

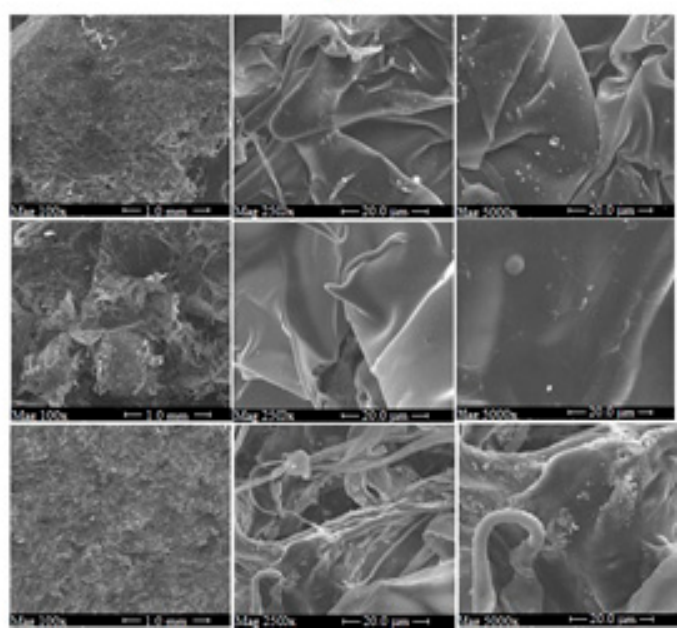

Figure 5. Scanning electron microscopy of crude (CG) and soluble glucans (SG) from J1 (jujubes of first harvesting), J2 (jujube of the second harvesting); J3 (jujube of the third harvesting).

The variation of the elemental composition in nitrogen, carbon, and oxygen in the glucan matrix before and after the harvesting as a function of the harvesting period was evaluated by wavelength dispersive spectroscopy (WDS). Table 5 shows the results of WDS point analyses, which were an average of five measurements in different points of each sample. The results showed that the main element in all samples, both crude and soluble glucans, was the carbon. Its percentage ranged from $17.9 \pm 0.4$ in CGJ1 to $19.3 \pm 1$ in CGJ2, while it increased in soluble samples. The oxygen percentage remained almost constant in the $10.4 \%-14.4 \%$ range in all samples, both crude and soluble. Nitrogen represented a small percentage compared to carbon and oxygen content, ranging from $0.4 \%$ in CGJ3 and SGJ3 to $1.5 \%$ in CGJ2. The results highlighted that harvesting stage determined some changes in elemental composition of glucans.

Table 5. Wavelength dispersive spectroscopy (WDS) measurements of the compositions in $w t \%$ of CGJ1 (crude glucans from jujubes of first harvesting); CGJ2 (crude glucans from jujubes of second harvesting); CGJ3 (crude glucans of jujubes at third harvesting); SGJ1 (soluble glucans from jujubes of first harvesting); SGJ2 (soluble glucans from jujubes of second harvesting); SGJ3 (soluble glucans from jujubes of third harvesting).

\begin{tabular}{ccccccc}
\hline \multirow{2}{*}{ Elements } & \multicolumn{5}{c}{ Samples } \\
\cline { 2 - 6 } & CGJ1 & SGJ1 & CGJ2 & SGJ2 & CGJ3 & SGJ3 \\
\hline N & $0.7 \pm 0.2$ & $0.6 \pm 0.1$ & $1.5 \pm 0.2$ & $1.1 \pm 0.2$ & $0.4 \pm 0.1$ & $0.4 \pm 0.1$ \\
C & $17.9 \pm 0.4$ & $36.7 \pm 3.2$ & $19.3 \pm 1$ & $33.4 \pm 3$ & $16.7 \pm 1.7$ & $23.3 \pm 1.3$ \\
O & $10.4 \pm 0.7$ & $14.4 \pm 2$ & $10.7 \pm 1.5$ & $10.5 \pm 1.5$ & $10.4 \pm 0.7$ & $11.5 \pm 0.9$ \\
\hline
\end{tabular}

The results are average of 5 measurements in different points of each sample \pm SD. 


\subsection{Cell Viability}

Keratinocytes constitute the major cellular component in the epidermis and are involved in the process of wound healing by providing a continuous supply of proliferative cells. For this reason, $\mathrm{HaCat}$ cell line were used as a model for studying the regenerative potential of glucans extracted from Italian jujube fruits at three harvesting periods and purified by dialysis process. HaCat cells were treated with different amount of CGJ1, CGJ2, and CGJ3 (10, 20, 50, and $100 \mu \mathrm{g})$. After $24 \mathrm{~h}$, any difference was observed at $10 \mu \mathrm{g}$ for CGJ1, CGJ2, and CGJ3, (Figure 6A,C,E), but a significant increase of cell viability was found at 20,50 , and $100 \mu \mathrm{g}$ with different statistic values ${ }^{* *} p<0.01$ at 20 , 50, $100 \mu \mathrm{g}$ of CGJ1; ${ }^{*} p<0.05$ at $20 \mu \mathrm{g}$; and ${ }^{* *} p<0.01$ at 50 and $100 \mu \mathrm{g}$ of CGJ2; ${ }^{* * *} p<0.001$ at 20, 50, and $100 \mu \mathrm{g}$ of CGJ3) (Figure 6A,C,E). The findings demonstrated that the activity of CGJ1, CGJ2, and CGJ3, at $24 \mathrm{~h}$, is dose dependent. After $48 \mathrm{~h}$, proliferative effect was observed even at $10 \mu \mathrm{g}$ of CGJ2 and CGJ3 $\left({ }^{*} p<0.05\right.$ and ${ }^{* *} p<0.01$, respectively); however, the findings were significantly highest at $100 \mu \mathrm{g}$ of CGJ2 and CGJ3 ${ }^{* * *} p<0.001$, Figure $\left.6 \mathrm{D}, \mathrm{F}\right)$. On the contrary, after $48 \mathrm{~h}$ of treatment with CGJ3, showed a dose-independent effect, as shown in Figure 6F. In any case, the most significant stimulus to cell viability came from CGJ3 both after 24 and $48 \mathrm{~h}$ (336.7\% and 351.7\%, respectively). In agreement with a previous report showing that $\beta$-glucans promote cell proliferation in different cell types [34], this biochemical behavior could be due to the higher number of $\beta$-glucans in CGJ3 fraction (Table 4) if compared to CGJ1 and CGJ2. Similar proliferative effects were observed for HaCaT cells treated with the corresponding soluble glucans SGJ1, SGJ2, and SGJ3 (Figure 7). The findings were not statistically significant at $10 \mu \mathrm{g}$ of SGJ1, SGJ2, and SGJ3 after 24h (Figure 7A,C,E), but cells treated with higher doses of soluble glucans showed a significant increase of cell viability with different statistic values ${ }^{* * *} p<0.001$ at 20,50, $100 \mu \mathrm{g}$ of SGJ1; $p<0.05$ at $20 \mu \mathrm{g},{ }^{* *} p<0.01$ at 50; and ${ }^{* * *} p<0.001$ at $100 \mu \mathrm{g}$ of SGJ2, respectively; ${ }^{* *} p<0.01$ at $20,50 \mu \mathrm{g}$ and ${ }^{* * *} p<0.001$ at $100 \mu \mathrm{g}$ of SGJ3). The best proliferative effects have been achieved by treating HaCaT cells with $100 \mu \mathrm{g}$ of SGJ3 after 24 and $48 \mathrm{~h}(370 \%$ and $379.7 \%$, respectively). The results showed that all the glucans displayed no toxicity for HaCaT cells using an MTT assay.
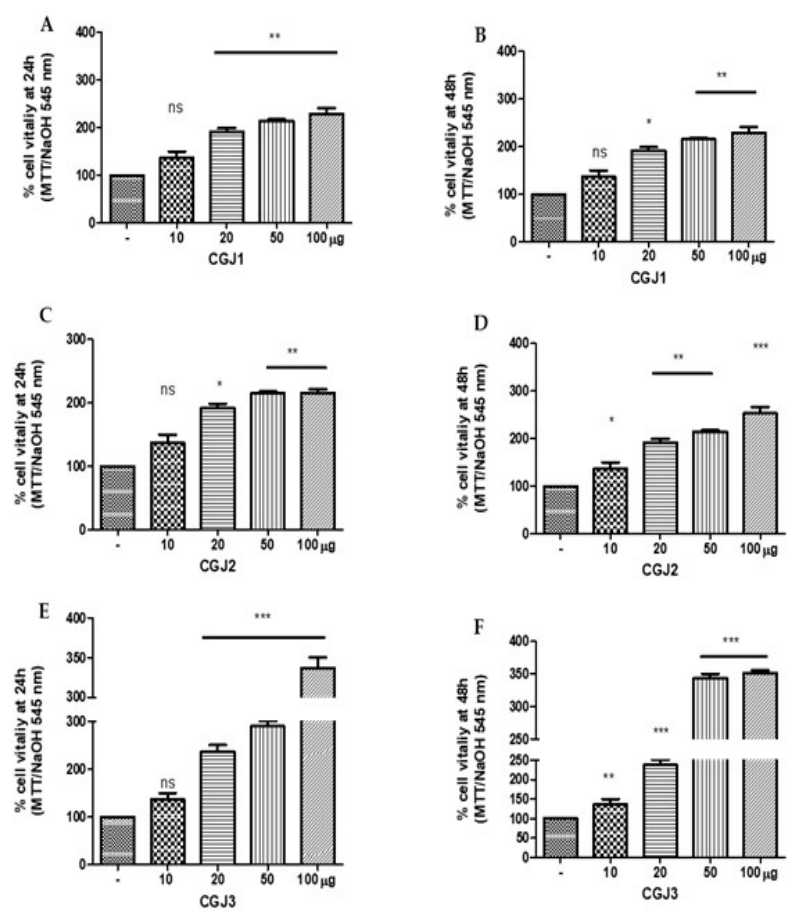

Figure 6. MTT assay of HaCat cells line treated with crude glucans (A) CGJ1 (crude glucans from jujubes of first harvesting); (C) CGJ2 (crude glucans from jujubes of second harvesting); (E) CGJ3 (crude glucans of jujubes at third harvesting) after $24 \mathrm{~h}$ and (B) CGJ1, (D) CGJ2, and (F) CGJ3 after $48 \mathrm{~h}$. ${ }^{*} p<0.05,{ }^{* *} p<0.01$ and ${ }^{* *} p<0.001$ in comparison with control. 

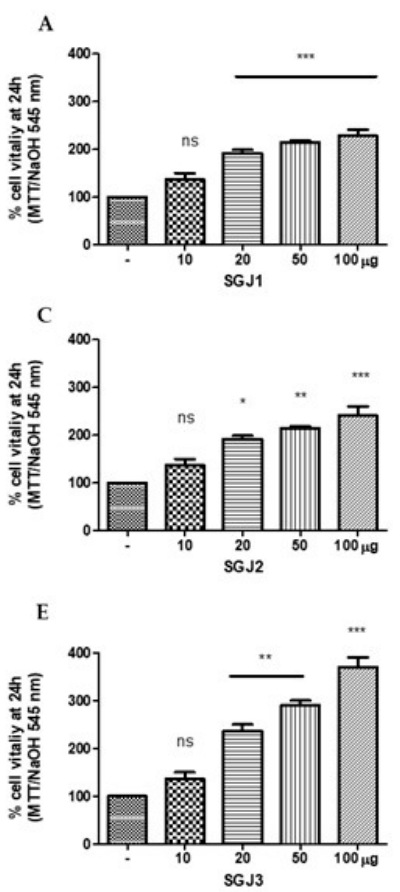
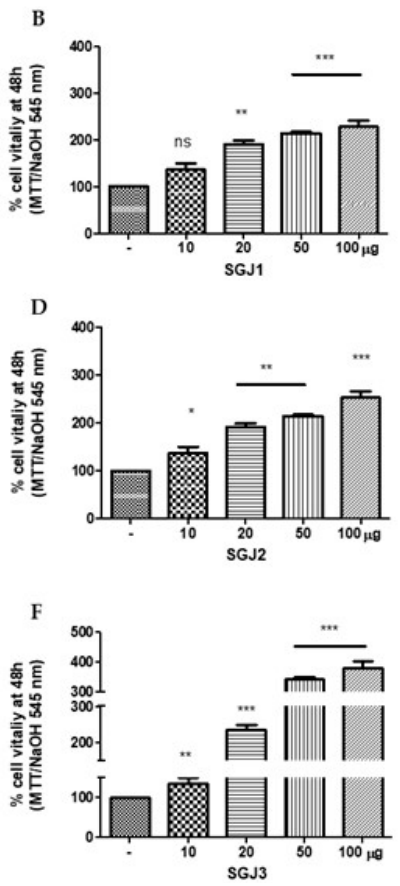

Figure 7. MTT assay of HaCat cells line treated with crude glucans (A) from SGJ1 (soluble glucans from jujubes of first harvesting); (C) SGJ2 (soluble glucans from jujubes of second harvesting); (E) SGJ3 (soluble glucans from jujubes of third harvesting) after $24 \mathrm{~h}$ and (B) SGJ1, (D) SGJ2, and (F) SGJ3 after 48 h. ${ }^{*} p<0.05,{ }^{* *} p<0.01$ and ${ }^{* * *} p<0.001$ in comparison with control.

\subsection{Scratch Assay}

The scratch wound healing assay has been used to evaluate the migration of cells, and to establish the influence of the traditional medicines on the keratinocytes. Owing to a slightly better proliferative effect on $\mathrm{HaCaT}$ cells of the soluble glucans (above all SGJ3) than the crude fractions, scratch assay was conducted on SG fraction-treated keratinocytes, in order to confirm that this fraction was involved in skin regeneration. The HaCat culture monolayer was incised in the central area in the presence of different amount of SGJ1, SGJ2, and SGJ3 (10, 20, 50, and $100 \mu \mathrm{g})$. The results are shown in Figure 8A-C. The scratch area was filled with migrating $\mathrm{HaCaT}$ cells.

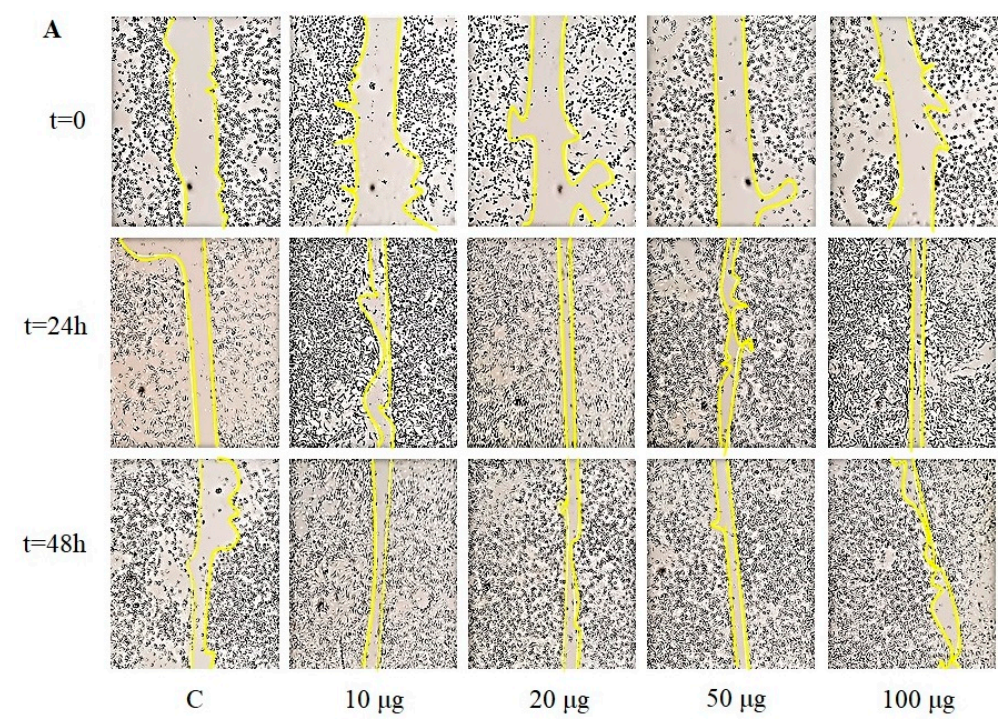

Figure 8. Cont. 


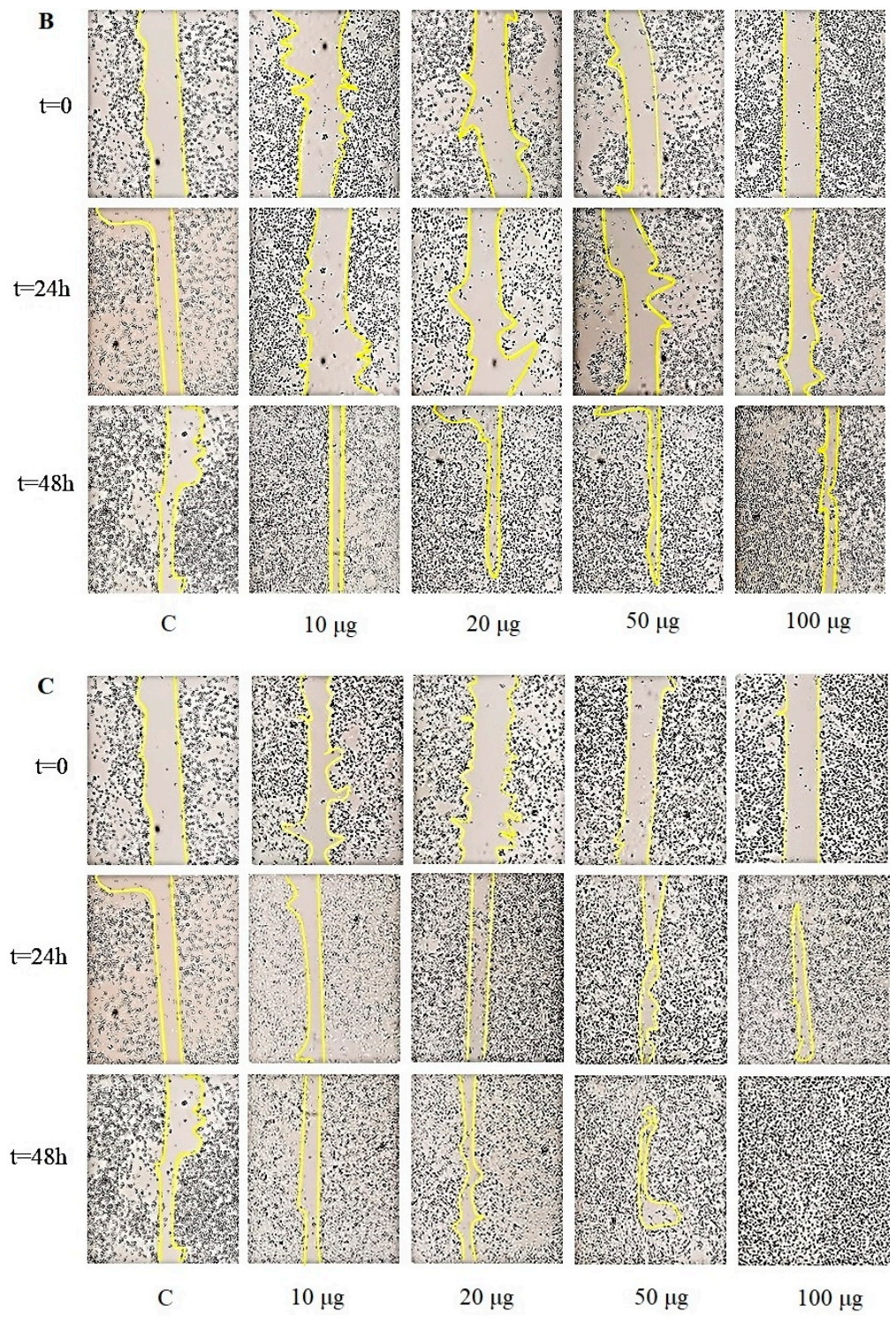

Figure 8. Representative images of time course scratch assay of HaCat cells treated with different concentration of soluble glucans (A) SGJ1 (soluble glucans from jujubes of first harvesting); (B) SGJ2 (soluble glucans from jujubes of second harvesting); and (C) SGJ3 (soluble glucans from jujubes of third harvesting), compared to control $(\mathrm{C}=$ untreated). Yellow line indicates the site of the scratch wound.

The images show that the cells treated with SGJ1 and SGJ2 exhibited visible closure of the scratch area compared to control already after $24 \mathrm{~h}$, but the best result was recorded at $48 \mathrm{~h}$ in which cellular migration was slowed down but kept stable (Figure 8A,B). Among all the groups, the cells treated with SGJ3 exhibited an excellent response already after $24 \mathrm{~h}$ at $100 \mu \mathrm{g}$. The wound area was completely restored after $48 \mathrm{~h}$ in the cells treated with 50 and $100 \mu \mathrm{g}$ of SGJ3 (Figure 8C). Therefore, the present study showed that soluble glucans extracted from jujubes prompt cellular survival and cell migration, which are critical in wound healing process. Cell migration is a hallmark of wound repair, which is a complex cellular and biochemical process necessary to restore structurally damaged tissue. What we noticed was a different capability of HaCaT cell migration: The properties of keratinocytes in chronic wounds can depend on the context in which the cell line is migrating because the cell migration occurs in different morphological variants [35]. A successful wound closure needs a crosstalk between the keratinocytes and other cell types involved in wound healing. Thus, the different results obtained for the groups treated with SG from J1, J2, and J3 were probably due to their diversified morphological structure (Figure 5), observing that SGJ3, which is the most effective in improving the wound healing 
abilities of keratinocytes, is also richer in layers. This structural aspect could influence the cell migration. Glucans, particular $\beta$-glucans in which the J3 fraction is rich, are able to act into the maturation of monocyte-derivatives dendritic cells as well as macrophage chemotactic recall into skin damage, both wound and surgical cut $[36,37]$. Furthermore, it is worth noting that only recently, four types of $\beta$-glucans extracted from different cereals promote epithelial cell migration. Moreover, Seo et al. did not record, in their set of experiments, the capability of HaCat to improve cell viability as it is evident in our results [18].

\section{Conclusions}

The results of the present study have conclusively indicated that the Ziziphus jujuba fruits could serve as a good source for the extraction of nutraceuticals and pharmaceuticals, such as glucans. It was found that their total content increased as the maturation proceeded, as well as the percentage of $\beta$ compared to $\alpha$-fraction. According to the anomeric structure of glucose units, FT-IR spectra of extracted glucans highlighted the simultaneous presence of both the $\alpha$ - and $\beta$-glycosidic anomeric bonds in all stages of harvesting, as confirmed by enzymatic assay. SEM showed significant morphological differences between the crude and the soluble glucans at each stage of maturation: The crude samples ranged from "pseudo-crystalline" in CGJ1, to amorphous structure of CGJ3, while soluble glucans exhibited a sheeting structure that becomes filamentous in SGJ3. The efficiency of different concentrations of crude and soluble glucans on survival and proliferation of the keratinocytes (HaCaT cells) was determined by MTT assay. The findings demonstrated that all fractions display no toxicity for the cells, but the best proliferative effects have been achieved by treating keratinocytes with higher doses of SGJ3 both after 24 and $48 \mathrm{~h}$. Among all the groups, the cells treated with the fraction containing the highest percentage of $\beta$-glucans (SGJ3), exhibited a good response promoting the complete closure of the wound area after $48 \mathrm{~h}$. Therefore, the present study showed that soluble glucans extracted from jujubes prompt cellular survival and cell migration, which are critical in wound healing process. These findings suggest that glucans from Ziziphus jujuba fruits was a potential therapeutic agent for skin repair.

Author Contributions: A.F. coordinated the work and wrote the manuscript; C.L.T. wrote the first draft and conducted experiment; M.C.C. revised the work; P.C. conducted morphological characterization of glucans; P.P. revised the work; E.C. facilitated, revised the work, and conducted biological experiment. All authors have read and agreed to the published version of the manuscript.

Funding: This research received no external funding.

Conflicts of Interest: The authors declare no conflict of interest.

\section{Abbreviations}

$\mathrm{J} 1$

$\mathrm{J} 2$

$\mathrm{J} 3$

MTT

MWCO

FT-IR

SEM

WDS

GOPOD

CGJ1

CGJ2

CGJ3

SGJ1

SGJ2

SGJ3 jujube from first harvesting

jujube from the second harvesting

jujube from the third harvesting

3-(4,5-dimethylthiasol-2-yl)-2,4-diphenyltetrazolium bromide

Molecular Weight Cut Off

Fourier Transform Infrared Spectroscopy

Scanning Electron Microscopy

wavelength dispersive spectroscopy

glucose-oxidase/peroxidase-reagent

crude glucans from jujubes of first harvesting

crude glucans from jujubes of second harvesting

crude glucans from jujubes of third harvesting

soluble glucans from jujubes of first harvesting

soluble glucans from jujubes of second harvesting

soluble glucans from jujubes of third harvesting 


\section{References}

1. Ghobadi, A.; Amini-Behbahani, F.; Yousefi, A.; Shirazi, M.T.; Behnoud, N. Medicinal and Nutritional Properties of Ziziphus jujuba Mill. in Traditional Persian Medicine and Modern Phytotherapy. Crescent J. Med. Biol. Sci. 2019, 6, 146-150.

2. Yao, S. Past, Present, and Future of Jujubes-Chinese Dates in the United States. Am. Soc. Hortic. Sci. 2013, 48, 672-680. [CrossRef]

3. Johnstone, R. Overcoming Barriers to Development of the Australian Jujube Industry; AgriFutures Australia: Wagga Wagga, Australia, 2018.

4. Plastina, P.; Bonofiglio, D.; Vizza, D.; Fazio, A.; Rovito, D.; Giordano, C.; Barone, I.; Catalano, S.; Gabriele, B. Identification of bioactive constituents of Ziziphus jujube fruit extracts exerting antiproliferative and apoptotic effects in human breast cancer cells. J. Ethnopharmacol. 2012, 140, 325-332. [CrossRef]

5. Plastina, P. Pharmacological Aspects of Jujubes. Pharmacologia 2016, 7, 243-255. [CrossRef]

6. Gabriele, B.; Fazio, A.; Carchedi, M.; Plastina, P. In vitro antioxidant activity of extracts of Sybaris liquorice roots from Southern Italy. Nat. Prod. Res. 2012, 26, 2176-2181. [CrossRef] [PubMed]

7. Plastina, P.; Apriantini, A.; Meijerink, J.; Witkamp, R.; Gabriele, B.; Fazio, A. In Vitro Anti-Inflammatory and Radical Scavenging Properties of Chinotto (Citrus myrtifolia Raf.) Essential Oils. Nutrients 2018, $10,783$. [CrossRef] [PubMed]

8. Shahrahmania, N.; Akbarib, S.A.A.; Mojabc, F.; Mirzaid, M.; Shahrahmania, H. The Effect of Zizyphus Jujube Fruit Lotion on Breast Fissure in Breastfeeding Women. Iran. J. Pharm. Res. 2018, 17, 101-109. [CrossRef]

9. San, B.; Yildirim, A.N. Phenolic, alpha-tocopherol, beta-carotene and fatty acid composition of four promising jujube (Ziziphus jujuba Miller) selections. J. Food Compos. Anal. 2010, 23, 706-710. [CrossRef]

10. Fustéa, N.P.; Guascha, M.; Guillenb, P.; Anerillasc, C.; Cemelia, T.; Pedrazaa, N.; Ferrezueloa, F.; Encinasc, M.; Moralejob, M.; Garía, E. Barley $\beta$-glucan accelerates wound healing by favoring migration versus proliferation of human dermal fibroblasts. Carbohydr. Polym. 2019, 210, 389-398. [CrossRef]

11. Muthuramalingam, K.; Choi, S.I.; Hyun, C.; Kim, Y.M.; Cho, M. $\beta$-Glucan-Based Wet Dressing for Cutaneous Wound Healing. Adv. Wound Care 2019, 8, 125-135. [CrossRef]

12. Wang, Q.; Sheng, X.; Shi, A.; Hu, H.; Yang, Y.; Liu, L.; Fei, L.; Liu, H. $\beta$-Glucans: Relationships between Modification, Conformation and Functional Activities. Molecules 2017, 22, 257. [CrossRef] [PubMed]

13. Vetvicka, V.; Vetvickova, J. Physiological effects of different types of $\beta$-glucan. Biomed. Pap. Med. Fac. Univ. Palacky Olomouc Czech Repub. 2007, 151, 225-231. [CrossRef] [PubMed]

14. Sletmoen, M.; Stokke, B.T. Higher Order Structure of (1,3)- $\beta$-D-Glucans and Its Influence on Their Biological Activities and Complexation Abilities. Biopolymers 2008, 89, 310-321. [CrossRef]

15. Gallelli, G.; Cione, E.; Serra, R.; Leo, A.; Citraro, R.; Matricardi, P.; Di Meo, C.; Bisceglia, F.; Caroleo, M.C.; Basile, S.; et al. Nano-hydrogel embedded with quercetin and oleic acid as a new formulation in the treatment of diabetic foot ulcer: A pilot study. Int. Wound J. 2019, 1-6. [CrossRef]

16. Stadelmann, W.K.; Digenis, A.G.; Tobin, G.R. Physiology and healing dynamics of chronic cutaneous wounds. Am. J. Surg. 1998, 176, 26S-38S. [CrossRef]

17. Darby, I.A.; Laverdet, B.; Bonte, F.; Desmouliere, A. Fibroblasts and myofibroblasts in wound healing. Clin. Cosmet. Investig. Dermatol. 2014, 7, 301-311. [CrossRef]

18. Seo, G.; Hyun, C.; Choi, S.; Kim, Y.M.; Cho, M. The wound healing effect of four types of beta-glucan. Appl. Biol. Chem. 2019, 62, 1-9. [CrossRef]

19. Wei, D.; Zhang, L.; Williams, D.L.; Browder, I.W. Glucan stimulates human dermal fibroblast collagen biosynthesis through a nuclear factor-1 dependent mechanism. Wound Repair Regen. 2002, 10, 161-168. [CrossRef]

20. McCleary, B.V.; Draga, A. Measurement of $\beta$-Glucan in Mushrooms and Mycelial Products. J. AOAC Int. 2016, 99, 364-373. [CrossRef]

21. Fazio, A.; Iacopetta, D.; La Torre, C.; Ceramella, J.; Muià, N.; Catalano, A.; Carocci, A.; Sinicropi, M.S. Finding solutions for agricultural wastes: Antioxidant and antitumor properties of pomegranate Akko peel extracts and $\beta$-glucan recovery. Food Funct. 2018, 9, 6618-6631. [CrossRef]

22. Fazio, A.; La Torre, C.; Dalena, F.; Plastina, P. Screening of glucan and pectin contents in broad bean (Vicia faba L.) pods during maturation. Eur. Food Res. Technol. 2020, 246, 333-347. [CrossRef] 
23. Yalçın, E.; Çelik, S.; İbanoğlu, E. Foaming properties of barley protein isolates and hydrolysates. Eur. Food Res. Technol. 2007, 226, 967-974. [CrossRef]

24. Joseph, M.M.; Aravind, S.R.; Varghese, S.; Mini, S.; Sreelekha, T.T. Evaluation of antioxidant, antitumor and immunomodulatory properties of polysaccharide isolated from fruit rind of Punica granatum. Mol. Med. Rep. 2012, 5, 489-496. [CrossRef] [PubMed]

25. Fazio, A.; Caroleo, M.C.; Cione, E.; Plastina, P. Novel acrylic polymers for food packaging: Synthesis and antioxidant properties. Food Packag. Shelf Life 2017, 11, 84-90. [CrossRef]

26. Perri, M.; Pingitore, A.; Cione, E.; Vilardi, E.; Perrone, V.; Genchi, G. Proliferative and anti-proliferative effects of retinoic acid at doses similar to endogenous levels in Leydig MLTC-1/R2C/TM-3 cells. Biochim. Biophys. Acta 2010, 1800, 993-1001. [CrossRef] [PubMed]

27. Perri, M.; Caroleo, M.C.; Cione, E. Basic Condition to Formazan Improve Sensitivity of the MTT Colorimetric Assay Dye. J. Biochem. Analyt. Stud. 2016, 1. [CrossRef]

28. Perri, M.; Yap, J.L.; Fletcher, S.; Cione, E.; Kane, M.A. Therapeutic potential of Bcl-xL/Mcl-1 synthetic inhibitor JY-1-106 and retinoids for human triple-negative breast cancer treatment. Oncol. Lett. 2018, 15, 7231-7236. [CrossRef]

29. Wang, Y.; Ahmed, Z.; Feng, W.; Li, C.; Song, S. Physicochemical properties of exopolysaccharide produced by Lactobacillus kefiranofaciens ZW3 isolated from Tibet kefir. Int. J. Boil. Macromol. 2008, 43, 283-288. [CrossRef]

30. Ahmad, A.; Anjum, F.M.; Zahoor, T.; Nawaz, H.; Ahmed, Z. Extraction and characterization of $\beta$-D-glucan from oat for industrial utilization. Int. J. Biol. Macromol. 2010, 46, 304-309. [CrossRef]

31. Kačuraková, M.; Capeka, P.; Sasinková, V.; Wellnerb, N.; Ebringerová, A. FT-IR study of plant cell wall model compounds: Pectic polysaccharides and hemicelluloses. Carbohydr. Polym. 2000, 43, 195-203. [CrossRef]

32. Mikkelsen, M.S.; Jespersen, B.M.; Møller, B.L.; Lærke, H.N.; Larsen, F.H.; Engelsen, S.B. Comparative spectroscopic and rheological studies on crude and purified soluble barley and oat $\beta$-glucan preparations. Food Res. Int. 2010, 43, 2417-2424. [CrossRef]

33. Limberger-Bayer, V.M.; de Francisco, A.; Chan, A.; Oro, T.; Ogliaru, P.J.; Barreto, P.L.M. Barley $\beta$-glucans extraction and partial characterization. Food Chem. 2014, 154, 84-89. [CrossRef] [PubMed]

34. Majtan, J.; Jesenak, M. $\beta$-Glucans: Multi-Functional Modulator of Wound Healing. Molecules 2018, $23,806$. [CrossRef] [PubMed]

35. Friedl, P.; Wolf, K. Tumour-cell invasion and migration: Diversity and escape mechanism. Nat. Rev. Cancer 2003, 3, 362-374. [CrossRef]

36. Sonck, E.; Devriendt, B.; Goddeeris, B.; Cox, E. Varying effects of different $\beta$-glucans on the maturation of porcine monocyte-derived dendritic cells. Clin. Vaccine Immunol. 2011, 18, 1441-1446. [CrossRef]

37. Rahar, S.; Swami, G.; Nagpal, N.; Nagpal, M.A.; Singh, G.S. Preparation, characterization, and biological properties of $\beta$-glucans. J. Adv. Pharm. Technol. Res. 2011, 2, 94-103. [CrossRef] 